\title{
ANALISIS SPASIAL EL NINO KUAT TAHUN 2015 DAN LA NINA LEMAH TAHUN 2016 (Pengaruhnya Terhadap Kelembapan, Angin dan Curah Hujan di Indonesia)
}

\author{
Spatial Analysis of the 2015 Strong El Nino and the 2016 Weak La Nina \\ (Their Influence on Humidity, Wind and Rainfall Conditions in Indonesia)
}

\author{
Ibnu Athoillah ${ }^{1)^{\star}}$, Rini Mariana Sibarani ${ }^{2)}$, Deassy Eirene Doloksaribu ${ }^{3)}$ \\ ${ }^{1,2)}$ Balai Besar Teknologi Modifikasi Cuaca - Badan Pengkajian dan Penerapan Teknologi, Gedung Ir. \\ Mohammad Soebagio, GEOSTECH (820), Kawasan PUSPIPTEK, Serpong, Tangerang Selatan \\ ${ }^{3)}$ Stasiun Meteorologi Kualanamu, BMKG Regional 1, JI Tengku Heran, Pasar V Kebun Kelapa, Deli \\ Serdang, Sumatera Utara \\ *E-mail : ibnu.athoillah@bppt.go.id
}

\begin{abstract}
Intisari
Kejadian El Nino Kuat tahun 2015 dan La Nina Lemah tahun 2016 sangat berpengaruh terhadap beberapa parameter cuaca di Indonesia seperti kelembapan udara, angin dan curah hujan. Dilihat dari kelembapan udara pada saat El Nino, kelembapan udara memiliki anomali negatif dan pada saat La Nina cenderung anomali positif. Dari pengaruhnya terhadap angin, saat El Nino angin zonal lebih dominan angin timuran, dan angin meridional lebih dominan angin selatan yang menyebabkan berkurangnya suplai uap air di Indonesia. Sedangkan saat La Nina, angin zonal lebih dominan baratan dan angin meridional lebih dominan dari utara. Data hujan yang digunakan dalam tulisan ini adalah data observasi per 1 jam dari satelit TRMM pada tahun 2015, 2016 dan data historis dari tahun 2001-2014. Dari hasil analisis spasial menunjukkan bahwa kejadian El Nino mulai terlihat dampaknya pada musim kering yaitu berupa penurunan curah hujan di bawah normalnya sekitar 50-300 mm/bulan terjadi pada bulan Agustus hingga Oktober 2015 terutama di wilayah Indonesia bagian Selatan sedangkan pada musim basah November 2015 - Maret 2016 tidak terlalu signifikan dampaknya. Kejadian La Nina terlihat dampaknya pada bulan SeptemberDesember tahun 2016 dimana terlihat adanya penambahan curah hujan dibandingkan normalnya sekitar 50-400 mm/bulan.
\end{abstract}

Kata Kunci : El Nino, La Nina, Kelembapan Udara, Angin, Hujan.

\begin{abstract}
Abtract
The strong El Nino in 2015 and the weak La Nina in 2016 are very influential on some weather parameters in Indonesia such as relative humidifty, wind, and rainfall. The relative humidity during El Nino tends to be a negative and when La Nina tends to be a positive anomaly. Impact to the wind during El Nino, zonal winds are dominant northern and meridional winds are dominant southern which leads to reduced supply of water vapor in Indonesia. While during La Nina, zonal winds are dominant western and meridional winds are dominant northern. Rainfall data used in this paper are the observation data from TRMM Satellite hourly from 2001-2016. Data were analyzed by monthly and seasonal analysis. From the result of spatial analysis shows the impact of El Nino began on dry season. That is decrease of rainfall below the normal around $50-300 \mathrm{~mm} / \mathrm{month}$ occurs in August to October 2015, especially in southern Indonesia. while in wet season November 2015 - March 2016 the impact is not significant. The impact of La Nina is seen in SeptemberDecember 2016, where there is an increase of rainfall above the normal around 50-400 $\mathrm{mm} /$ month.
\end{abstract}

Keywords : El Nino, La Nina, Relative Humidity, Winds, Rainfall

\section{PENDAHULUAN}

Indonesia merupakan negara yang dilewati oleh garis khatulistiwa serta dikelilingi oleh dua samudra dan dua benua. Posisi ini menjadikan Indonesia sebagai daerah pertemuan sirkulasi meridional (Utara-Selatan) yang dikenal sebagai
Sirkulasi Hadley dan sirkulasi zonal (Timur-Barat) dikenal sebagai Sirkulasi Walker, dua sirkulasi yang sangat mempengaruhi keragaman iklim di Indonesia. Pergerakan matahari yang berpindah dari $23.5^{\circ}$ Lintang Utara ke $23.5^{\circ}$ Lintang Selatan sepanjang tahun mengakibatkan timbulnya aktivitas moonson yang juga ikut berperan dalam 
mempengaruhi keragaman iklim. Pengaruh lokal terhadap keragaman iklim juga tidak dapat diabaikan, karena Indonesia merupakan negara kepulauan dengan bentuk topografi yang sangat beragam, menyebabkan pengaruh kondisi lokal cukup dominan. Faktor lain yang diperkirakan ikut berpengaruh terhadap keragaman iklim di Indonesia ialah gangguan siklon tropis. Semua aktivitas dan sistem ini berlangsung secara bersamaan sepanjang tahun akan tetapi besar pengaruh dari masing-masing aktivitas atau sistem tersebut tidak sama dan dapat berubah dari tahun ke tahun (Boer, 2003).

Salah satu pengaruh global yang berpengaruh terhadap curah hujan di Indonesia adalah Fenomena El Nino dan La Nina. El Nino secara ilmiah diartikan sebagai fenomena global dari sistem interaksi laut dan atmosfer yang ditandai dengan meningkatnya suhu muka laut atau SST (Sea Surface Temperature) di sekitar Pasifik Tengah dan Timur sepanjang equator dari nilai rata-ratanya. Sedangkan La Nina adalah kebalikan dari El Nino, yaitu suatu kondisi dimana terjadi penurunan suhu muka laut di kawasan Timur equator di Lautan Pasifik dari rata-ratanya (Aldrian, 2002, Aldrian \& Susanto, 2003; Hendon, 2003; Irawan, 2006; Meyers et al, 2007). Fenomena ini merupakan salah satu akibat dari penyimpangan iklim yang akan menyebabkan penurunan dan peningkatan jumlah curah hujan untuk beberapa daerah di Indonesia.

Menurut Boer (2014) sejak tahun 1844 hingga 2009 di Indonesia telah mengalami kejadian kekeringan atau jumlah curah hujan di bawah rata-rata normal tidak kurang dari 47 kali. Dari 47 kali kejadian tersebut hanya 6 kali kejadiannya tidak bersamaan dengan kejadian fenomena El Nino, hal ini menunjukkan bahwa keragaman hujan di Indonesia sangat dipengaruhi oleh fenomena ini. Dari beberapa hasil tersebut ingin diketahui sebaran spasial pengaruh dari kejadian El Nino pada tahun 2015 dan La Nina tahun 2016 terhadap curah hujan di Indonesia.

\section{METODE}

Data yang digunakan dalam penelitian ini adalah data curah hujan yang berasal dari data GSMAP (Global Satellite Mapping of Precipitation) berupa data per 1jam dengan resolusi $0.1^{0} \times 0.1^{0}$. Dengan data curah hujan yang berasal dari satelit ini diharapkan dapat memberikan sebaran spasial yang lebih baik dibandingkan dengan menggunakan data dari pos penakar hujan yang jumlahnya terbatas.

Produk dari TRMM ini telah banyak digunakan untuk berbagai aplikasi diantaranya pemantauan cuaca/ iklim, analisis iklim, verifikasi model numerik dan studi hidrologi (Xie et al, 2007). Hubungan antara data TRMM dengan data lapangan dari penakar BMKG cukup tinggi terutama untuk pola hujan bulanan (As-syakur et al., 2010). Daerah cakupan penelitiannya meliputi wilayah Indonesia pada koordinat $6^{\circ} \mathrm{LU}-11^{\circ} \mathrm{LS}$ dan $95^{\circ} \mathrm{BT}-140^{\circ} \mathrm{BT}$. Data gsmap near realtime yang digunakan adalah data per 1jam selama 16 tahun dari tahun 2001 sampai dengan tahun 2016, dengan tahun 2015 sebagai tahun EI Nino dan tahun 2016 sebagai tahun EI Nino La Nina. Selain itu, di dalam kajian ini juga menggunakan data kelembapan $(\mathrm{RH})$ pada level 850-500 mb, serta angin zonal dan meridional dari NCEP NCAR Reanalysis (NNR). Periode data yang digunakan dari tahun 1979 sampai tahun 2016. Data tersebut memiliki resolusi spasial $2.50^{\circ} \mathrm{x}$ $2.50^{\circ}$ dan resolusi temporal bulanan dengan sumber datanya didapat dari www.esrl.noaa.gov/psd/data/gridded/.

Rata-rata curah hujan sebagai gambaran kondisi curah hujan normal di Indonesia dengan menggunakan data historis gsmap dari tahun 2001 sampai dengan tahun 2014 akan dibandingkan dengan data curah hujan aktual tahun 2015 dan 2016 untuk mendapatkan data anomali curah hujan tahun 2015 dan 2016. NOAA menyatakan El Nino pada tahun 2015 dimulai pada periode Februari-Maret-April 2015 hingga Maret-April-Mei 2016. Sedangkan menurut BMKG, La Nina terjadi dari bulan Juli hingga September 2016.

Untuk melihat dampak dari dua fenomena tersebut akan dilihat dari, pola kelembapan udara pada beberapa lapisan, arah angin dan anomali curah hujan yang terjadi dengan analisis spasial. Software yang digunakan dalam penelitian ini adalah GrADS.

\section{HASIL DAN PEMBAHASAN}

Wilayah Indonesia pada koordinat $6^{\circ} \mathrm{LU}-$ $11^{\circ} \mathrm{LS}$ dan $95^{\circ} \mathrm{BT}-140^{\circ} \mathrm{BT}$, pada pertengahan tahun 2015 hingga awal tahun 2016 ikut merasakan fenomena El Nino Kuat yang berpengaruh terhadap penurunan curah hujan. Sedangkan pada pertengahan hingga akhir tahun 2016 ikut merasakan fenomena La Nina Lemah hingga normal. Fenomena El Nino ditandai dengan anomali SST bernilai positif lebih dari $0,5^{\circ} \mathrm{C}$ (yang apabila nilai anomali SST lebih besar dari $+1,5^{0}$ berarti El Nino kuat) dan fenomena La Nina ditandai dengan anomali SST bernilai negatif kurang dari $-0,5^{\circ} \mathrm{C}$. Terjadinya fenomena El Nino Kuat pada tahun 2015 dan La Nina Lemah pada tahun 2016 dapat dilihat pada Gambar 1.

Fenomena El Nino kuat terjadi pada bulan Agustus 2015 - Maret 2016. Selama terjadi El Nino Kuat pada tahun tersebut kondisi atmosfer terbagi dua, yaitu bulan kering (Agustus Oktober) dan bulan basah (November - Maret). Selain El Nino, fenomena La Nina lemah yang terjadi pada bulan Juli - Desember 2016 juga akan dilihat pengaruhnya terhadap kelembapan, angin dan curah hujan. 


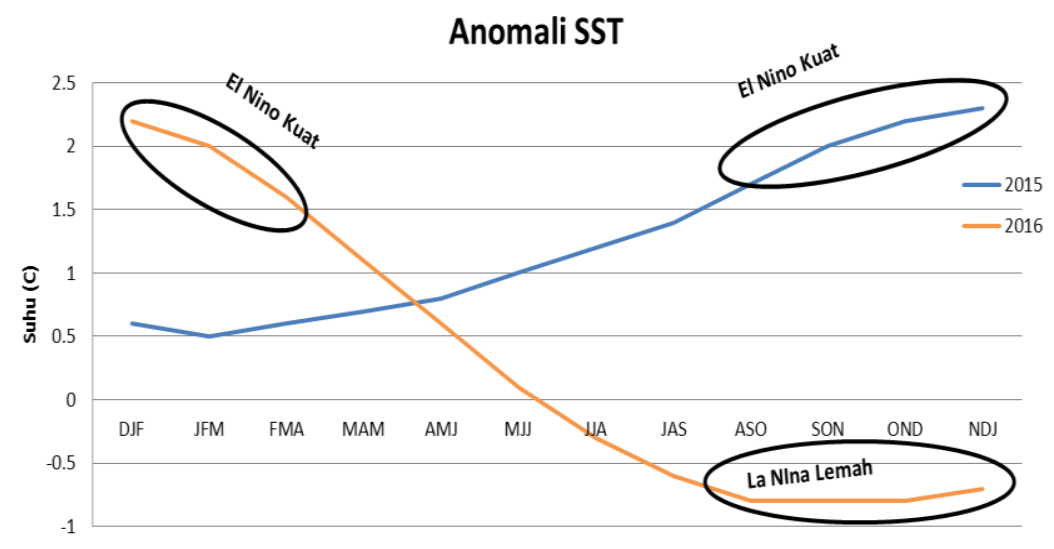

Gambar 1. Anomali SST Tahun 2015 dan 2016. Grafik yang dilingkari menunjukkan kejadian El Nino Kuat (nilai anomali SST diatas $1,5^{\circ} \mathrm{C}$ ) dan La Nina Lemah (nilai anomali SST di atas $0,5^{\circ} \mathrm{C}$ ). (sumber : http://www.cpc.ncep.noaa.gov/products/analysis_monitoring/ensostuff/ensoyears.shtml)

\subsection{Kelembapan $(R H)$}

Pengaruh El Nino pada bulan basah dan bulan kering di wilayah Indonesia juga berdampak pada kelembapan udara (Relative Humidity) di wilayah tersebut. Perhatikan Gambar 2 yang menunjukkan anomali kelembapan udara di Indonesia pada lapisan 850 $\mathrm{mb}, 700 \mathrm{mb}$ dan $500 \mathrm{mb}$. Terlihat adanya perbedaan pada ke-tiga lapisan udara tersebut.

Untuk bulan kering Juli-Oktober 2015 (Gambar 2a), kelembapan udara pada lapisan $850 \mathrm{mb}$ rata-rata mengalami penurunan sekitar $5-20 \%$ dari normalnya pada wilayah Indonesia bagian Selatan dan Timur, sedangkan untuk wilayah Indonesia bagian Barat (hanya pada bulan Juli-Agustus 2015) kelembapan udara pada lapisan $850 \mathrm{mb}$ normal atau bahkan meningkat sekitar $20 \%$ dari normalnya. Untuk lapisan $700 \mathrm{mb}$ dan $500 \mathrm{mb}$ wilayah Indonesia relatif mengalami penurunan kelembapan sekitar $10 \%$ sampai di atas $20 \%$ dari normalnya. Hal ini menyebabkan sulitnya terjadi pertumbuhan awan di wilayah Indonesia.

Pada bulan basah November 2015 - Maret 2016 (Gambar 2b) kelembapan pada lapisan 850 $\mathrm{mb}$ hingga $500 \mathrm{mb}$ di wilayah Indonesia mulai membaik. Terlihat adanya peningkatan kelembapan di tiap lapisan udara sekitar 5-20\% dari normalnya di wilayah Indonesia Bagian Barat dan Timur. Sedangkan di Indonesia bagian Selatan kelembapan udara mengalami penurunan sekitar $2-20 \%$ dari normalnya. Hal ini juga menyebabkan pertumbuhan awan sedikit terganggu pada bulan basah di wilayah Indonesia bagian Selatan.

Gambar 2 dan Gambar 3 menjelaskan kondisi kelembapan di wilayah Indonesia selama kejadian El Nino Kuat dan La Nina Lemah. Terlihat jelas perbedaannya, dimana pada Gambar 3 anomali kelembapan lebih dominan positif di berbagai lapisan. Hal ini menunjukkan kondisi Indonesia pada Gambar 3 lebih mudah terjadi pertumbuhan awan-awan hujan.

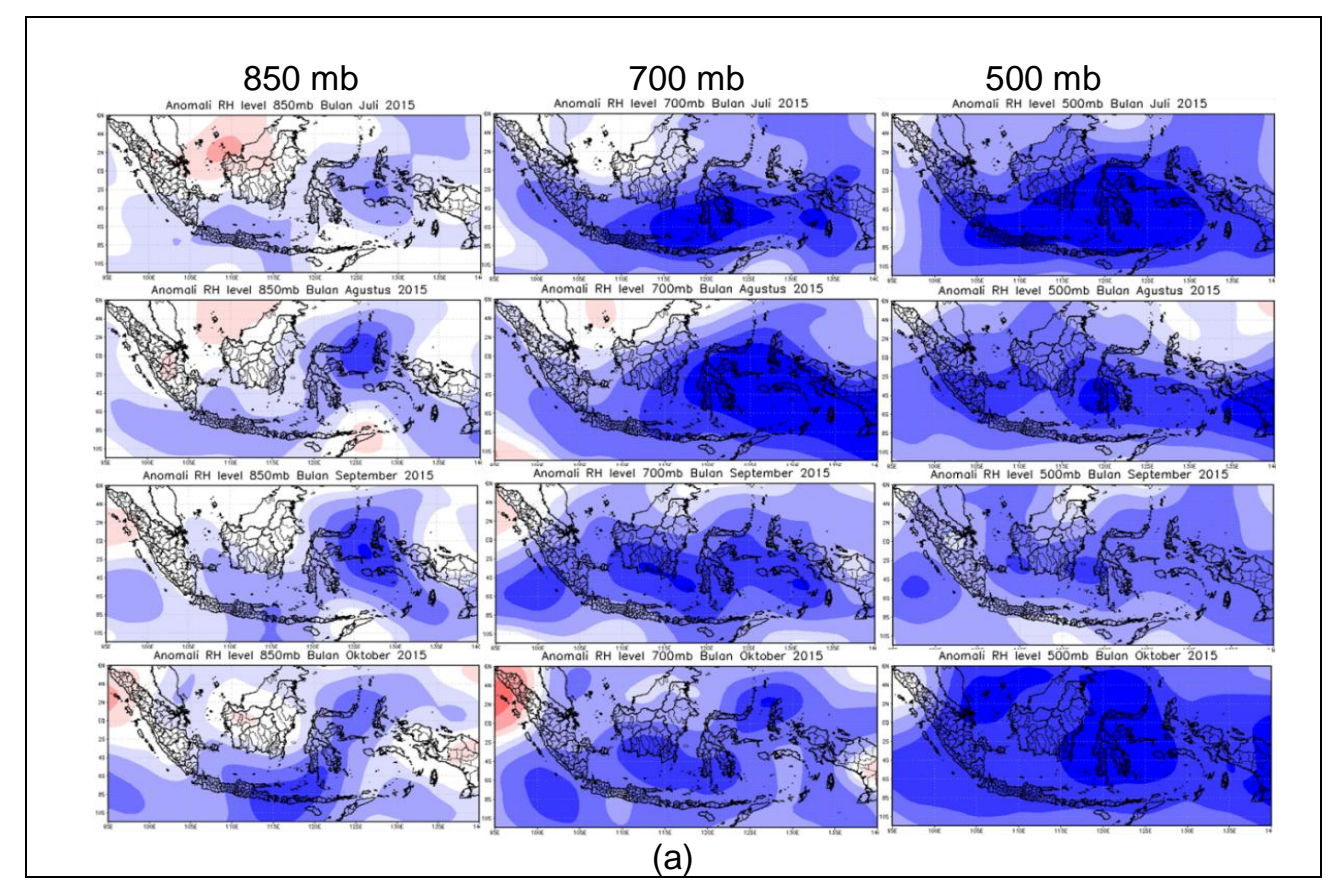




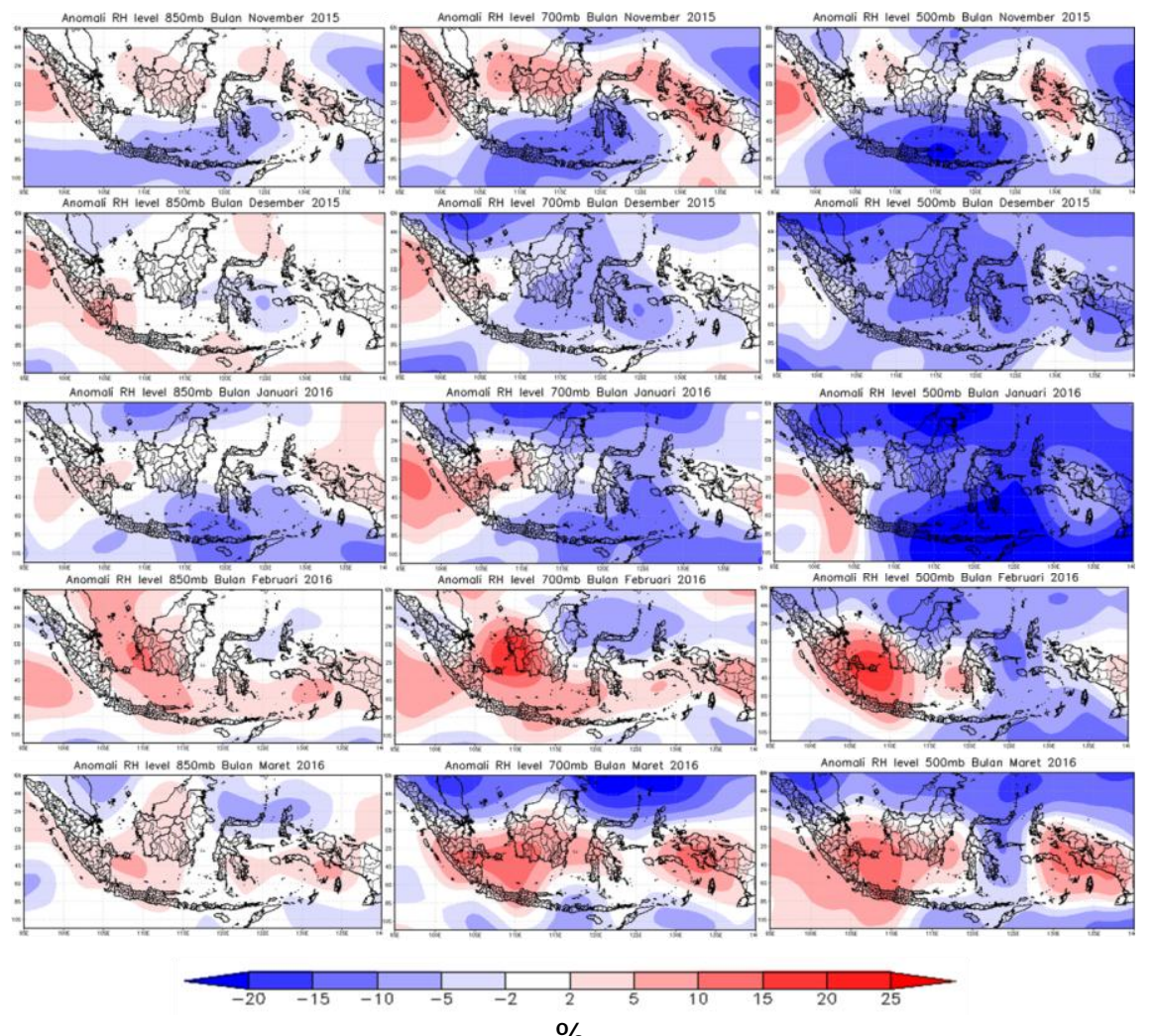

(b)

Gambar 2. Anomali kelembapan wilayah Indonesia pada lapisan 850, 700 dan $500 \mathrm{mb}$ di bulan Agustus 2015 - Maret 2016.

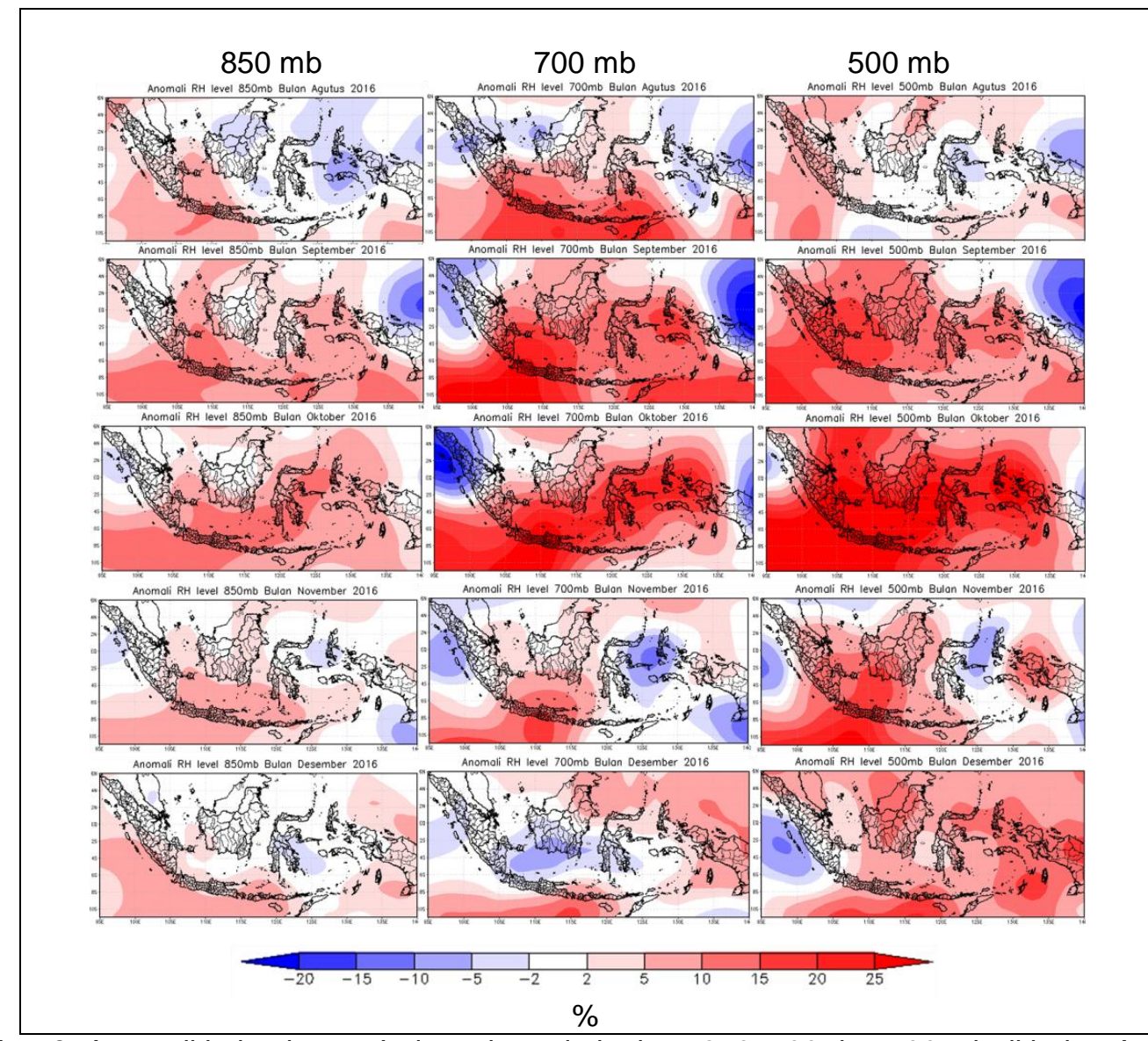

Gambar 3. Anomali kelembapan Indonesia pada lapisan 850, 700 dan 500 mb di bulan AgustusDesember 2016. 


\subsection{Angin}

Angin merupakan udara yang bergerak karena adanya perbedaan tekanan udara, dimana arah aliran angin dari tempat yang bertekanan tinggi ke tempat yang bertekanan rendah atau dari tempat yang bersuhu rendah ke tempat yang bersuhu tinggi. Gerak media di atmosfer terhadap permukaan bumi mempunyai dua arah yaitu arah horizontal sesuai permukaan bumi dan arah vertikal dari permukaan (Prawirowardoyo, 1996).

Gerakan arah horizontal angin terbagi lagi menjadi dua arah yaitu arah lintang dan arah bujur, untuk arah timur barat disebut sebagai angin zonal dan untuk arah selatan utara disebut sebagai angin meridional. Pada saat musim basah angin zonal bertiup dari barat dan pada musim kering bertiup dari timur. Sedangkan angin meridional pada saat musim basah bertiup dari utara dan saat musim kering bertiup dari selatan (Aldrian, 2000; Visa et al, 2012).

Menurut Mulyana (2002), berdasarkan rata-rata tiga bulanan diperoleh bahwa pada tahun EI Nino terjadi penguatan angin timuran pada periode Maret-April-Mei dan SeptemberOktober-November. Sementara pada periode Juni-Juli-Agustus angin timuran yang berhembus di wilayah Indonesia terutama di sebelah selatan equator tidak mengalami perubahan berarti. Sedangkan pada periode Desember-JanuariFebruari angin baratan yang berhembus di wilayah Indonesia sebelah selatan equator kecepatannya melemah.

Gambar 4 menampilkan anomali angin zonal dan angin meridional di wilayah Indonesia pada saat terjadi El Nino kuat pada bulan kering Agustus-Desember 2015 dan La Nina Lemah pada bulan Agustus-Desember 2016.

Terlihat pada saat El Nino kuat (AgustusDesember 2015), angin zonal dominan bernilai negatif dari ekuator hingga ke selatan wilayah Indonesia pada bulan Agustus-November 2015 dan mulai membaik (bernilai positif) pada bulan Desember 2015. Hal ini menunjukkan bahwa angin zonal lebih dominan angin timuran yang mengandung sedikit uap air. Sama hal nya dengan angin meridional pada saat El Nino kuat, angin yang bertiup lebih dominan angin positif yang bertiup dari selatan menuju utara pada bulan Agustus hingga Oktober 2015. Angin yang menuju ke arah Utara ini juga mengandung sedikit uap air. Hal ini menyebabkan di wilayah Indonesia mengalami penurunan jumlah curah hujan pada bulan Agustus-Oktober 2015 dan mulai membaik pada bulan Desember 2015.

Pada saat La Nina lemah angin zonal dominan bernilai positif (angin baratan) yang membawa uap air cukup banyak, bahkan jelas terlihat pada bulan Desember 2016. Sedangkan angin meridional dominan bernilai negatif (angin bergerak ke selatan). Hal ini menyebabkan pada bulan Agustus-Desember 2016 jumlah curah

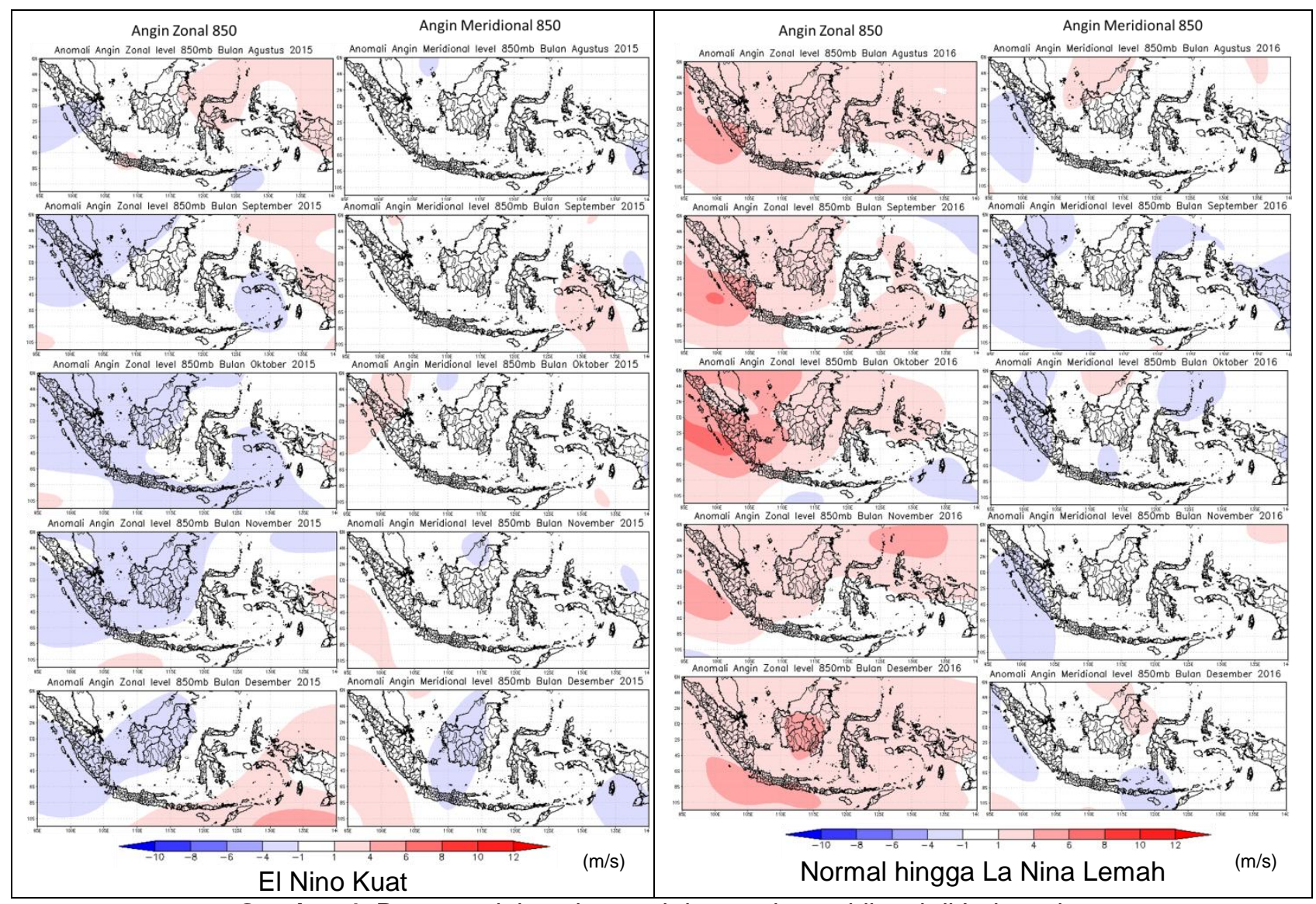

Gambar 4. Peta spasial angin zonal dan angin meridional di Indonesia. 
hujannya sama atau lebih banyak dari normalnya. Dari gambar spasial angin zonal dan meridional tersebut dapat menjelaskan bahwa El Nino dan La Nina juga mempengaruhi angin di Indonesia.

Resultan dari angin zonal dan angin meridional dapat dilihat pada Gambar 5. Pola spasial angin lapisan $850 \mathrm{mb}$ pada bulan Agustus-Desember saat El Nino kuat dan La Nina lemah tidaklah terlihat perbedaan yang signifikan. Pada bulan Agustus-Oktober angin dominan bertiup dari tenggara menuju equator dan di belokkan ke arah timur laut dan pada bulan November-Desember angin dominan bertiup dari timur laut menuju equator dan dibelokkan ke arah tenggara.

Jika diamati dari gambar spasial stream line angin, El Nino dan La Nina tidak mempengaruhi arah resultan angin. Tetapi dari pengamatan pada saat La Nina lemah terlihat adanya pusat tekanan rendah di Timur Laut Indonesia.

\subsection{Curah Hujan}

Pola spasial pengaruh El Nino tahun 2015 dan La Nina Tahun 2016 terhadap curah hujan di wilayah Indonesia dapat dilihat dari gambar 6 . Dari gambar 6 terlihat adanya penurunan curah hujan $(50-300 \mathrm{~mm}$ ) di wilayah Indonesia pada bulan kering (Agustus-Oktober 2015). Curah hujan normalnya pada bulan Agustus-Oktober berkisar 100-400 $\mathrm{mm} /$ bulan dan pada November-Desember berkisar 300-700 $\mathrm{mm} /$ bulan. Secara aktual curah hujan yang terjadi pada periode bulan kering (AgustusOktober 2015) seperti ditunjukkan dalam gambar 7. Curah hujan aktual yang terjadi pada periode
El-Nino Kuat
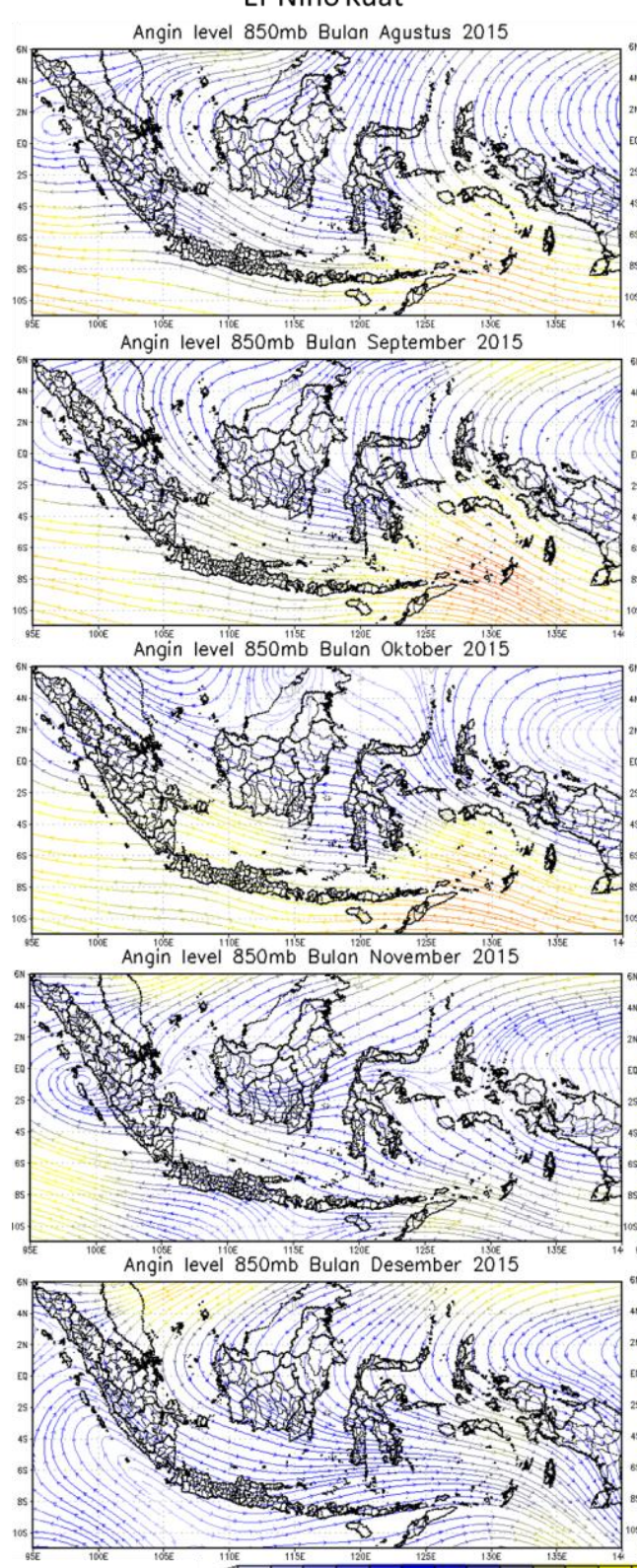

La-Nina Lemah

Angin level $850 \mathrm{mb}$ Bulan Agustus 2016

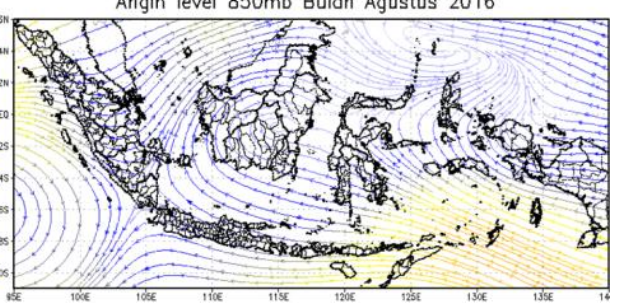

Angin level 850 mb Bulan September 2016

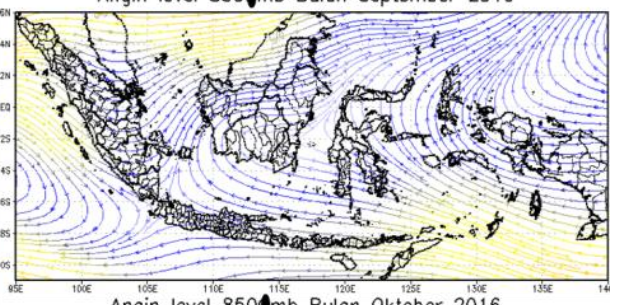

Angin level 850 ing $\mathrm{mb}$ Bulan Oktober 2016
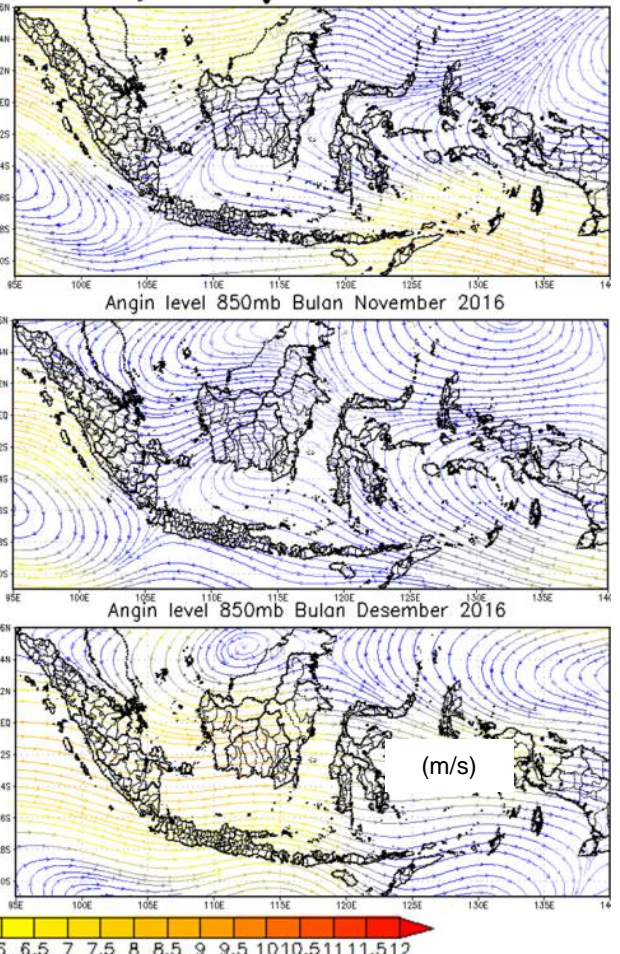

Gambar 5. Pola spasial angin 850 mb di Indonesia Juli-Desember 2015 dan Juli-Desember 2016. 
bulan kering tersebut adalah dibawah 100 $\mathrm{mm} /$ bulan, sedangkan pada bulan basah (November-Desember 2015) curah hujan aktualnya sebesar $200-700 \mathrm{~mm} /$ bulan. Dari pola spasial kejadian hujan tersebut dapat diketahui pengaruh El Nino Kuat pada tahun 2015 terhadap wilayah Indonesia ada di Bagian Selatan seperti Jawa, Bali, Nusa Tenggara dan Sulawesi Bagian Selatan hal tersebut cukup nampak pengaruhnya pada bulan kering yaitu (Agustus-Oktober). Sementara memasuki periode bulan basah (November-Desember) efek dari El Nino terhadap curah hujan yang terjadi tidak terlalu signifikan.

Pada saat La Nina lemah terlihat adanya penambahan curah hujan cukup signifikan pada bulan September-Desember 2016. Pada periode La Nina, terlihat anomali curah hujan bernilai positif yang berarti adanya penambahan curah hujan dari normalnya yang berkisar antara 50$400 \mathrm{~mm} /$ bulan. Sedangkan pada bulan Agustus 2016 nampak curah hujan memiliki anomali negatif hingga normal yang berarti kejadian hujan yang terjadi pada saat itu cukup kecil terutama di wilayah Jawa karena memang pada waktu tersebut adalah puncaknya musim kemarau di wilayah Jawa. Pada periode bulan SeptemberDesember 2016 curah hujan aktual yang terjadi berada pada kisaran diatas $300-800 \mathrm{~mm} /$ bulan.

Dari gambar 7 terlihat perbedaan yang cukup signifikan saat kondisi EI Nino dan La Nina terhadap curah hujan dimana pada saat El Nino curah hujan yang terjadi masih sedikit pada periode Agustus hingga Oktober dan saat La Nina dalam periode waktu yang sama sudah banyak intensitas hujan di wilayah Indonesia.
El-Nino Kuat

Anomali Curah Hujon Bulan Agustus 2015

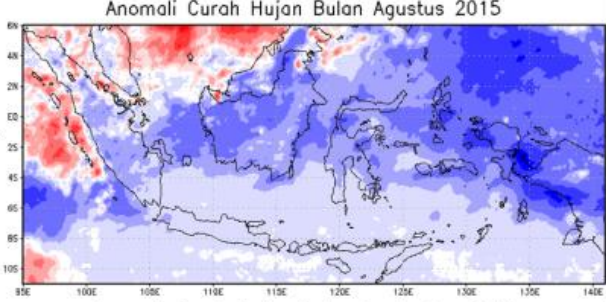

Anomali Curah Hujan Bulan September 2015

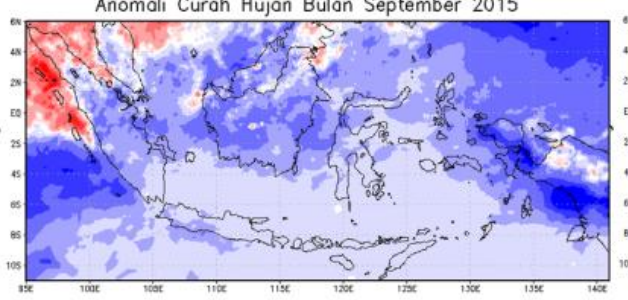

Anomali Curah Hujon Bulan Oktober 2015

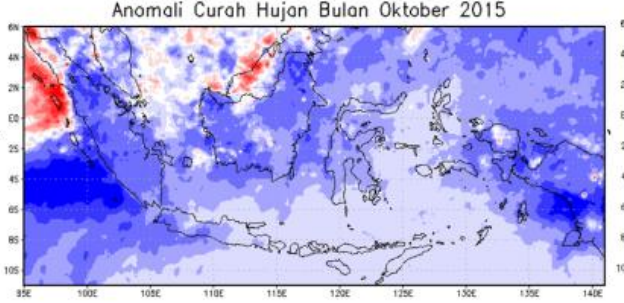

Anomali Curah Hujan Bulan november 2015

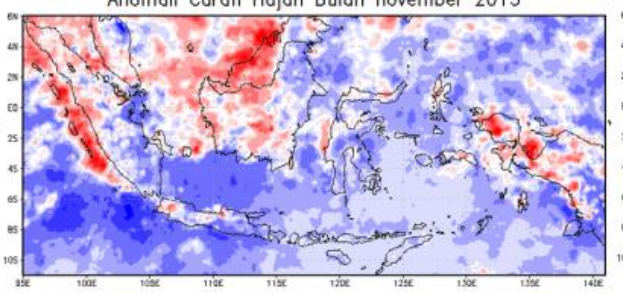

Anomali Curah Hujan Bulan Desember 2015

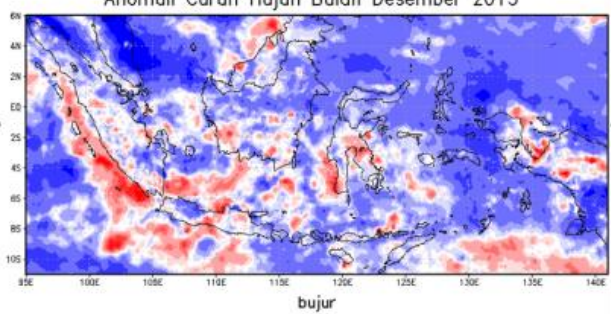

La-Nina Lemah

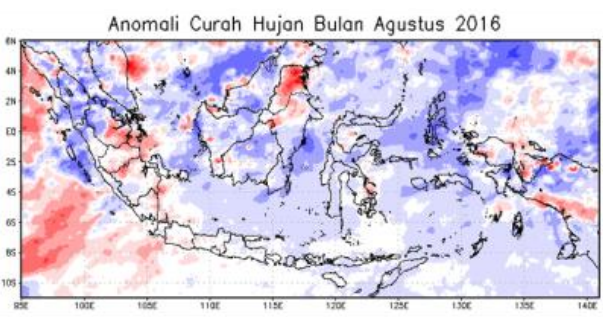

Anomali Curah Hujan Bulan September 2016

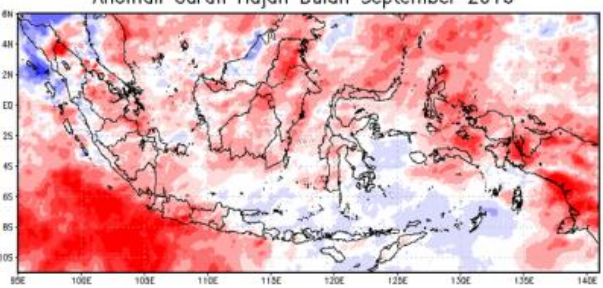

Anomali Curah Hujan Bulan Oktober 2016

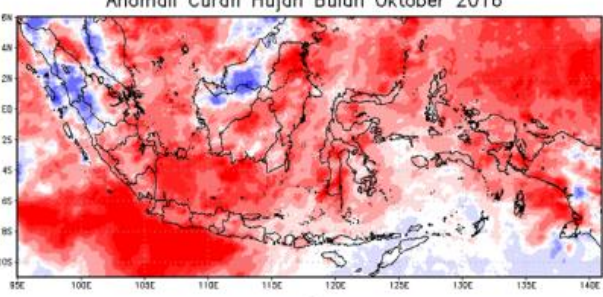

Anomali Curah Hujan Bulan November 2016

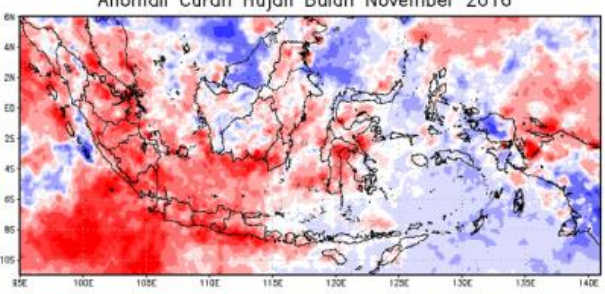

Anomali Curah Hujan Bulan Desember 2016

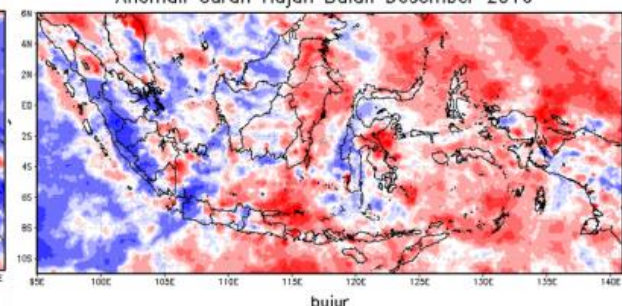

bujur

Gambar 6. Peta anomali curah hujan saat El Nino kuat dan La Nina Lemah. 
El-Nino Kuat

AKUMULASI CURAH HUJAN BULAN AGUSTUS 2015

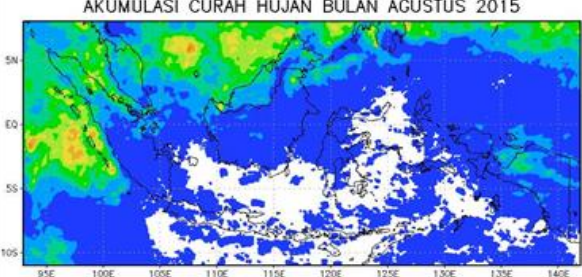

AKUMULASI CURAH HUJAN BULAN SEPTEMBER 2015

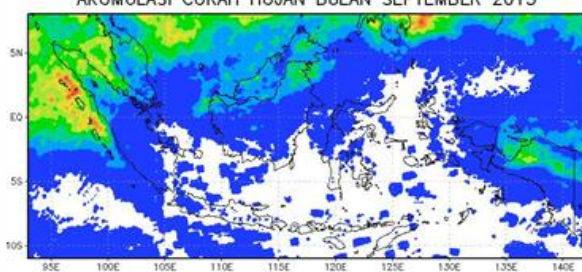

AKUMULASI CURAH HUJAN BULAN OKTOBER 2015

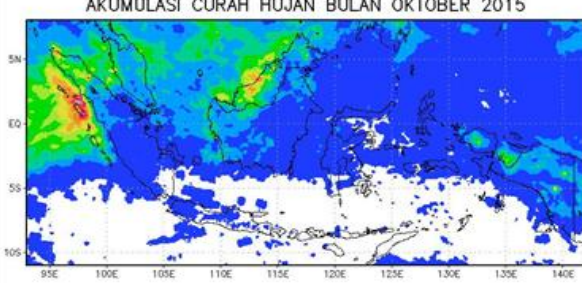

AKUMULASI CURAH HUJAN BULAN NOVEMBER 2015

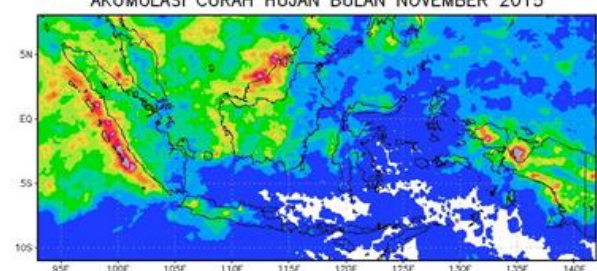

AKUMULASI CURAH HUJAN BULAN DESEMBER 2015

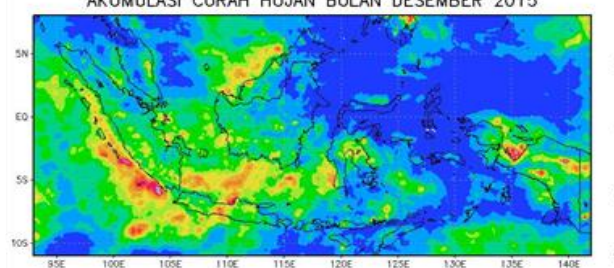

La-Nina Lemah

AKUMULASI CURAH HUJAN BULAN AGUSTUS 2016

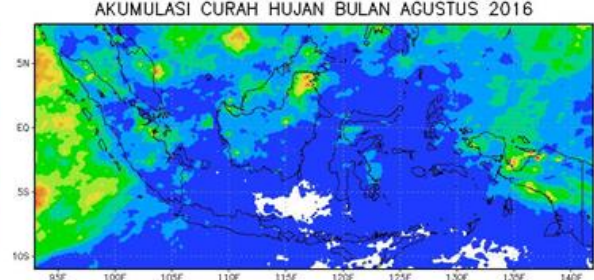

AKUMULASI CURAH HUJAN BULAN SEPTEMBER 2016

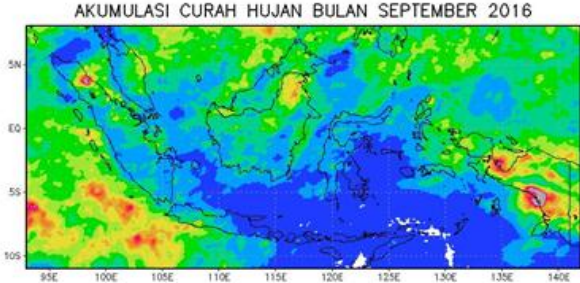

AKUMULASI CURAH HUJAN BULAN OKTOBER 2016

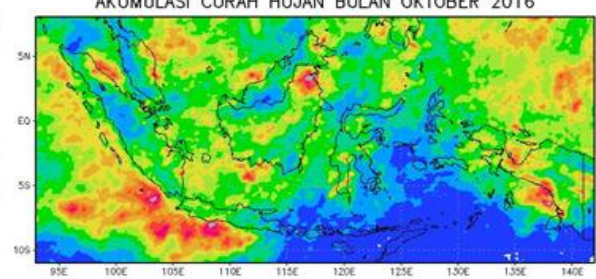

AKUMULASI CURAH HUJAN BULAN NOVEMBER 2016

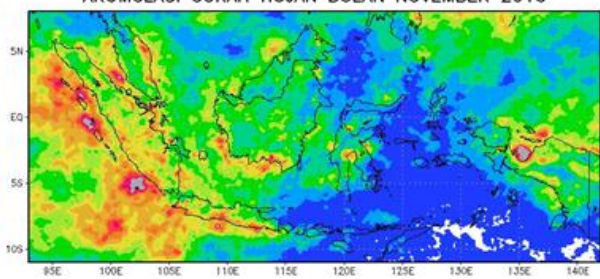

AKUMULASI CURAH HUJAN BULAN DESEMBER 2016

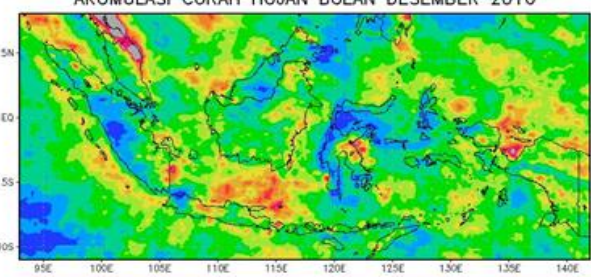

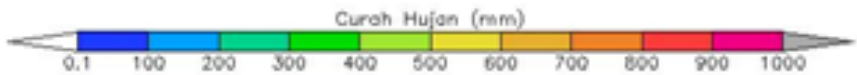

Gambar 7. Pola spasial curah hujan saat El Nino kuat dan La Nina Lemah.

\section{KESIMPULAN}

Penelitian ini dapat menggambarkan pengaruh dari fenomena El Nino dan La Nina yang terjadi pada tahun 2015 dan 2016 terhadap wilayah Indonesia dilihat dari beberapa parameter yaitu kelembapan udara, angin dan curah hujan. El Nino jelas terlihat pengaruhnya pada saat bulan kering (Juli-Oktober 2015), karena menurunkan nilai kelembapan dan mengurangi intensitas curah hujan.

Dari parameter kelembapan udara, pengaruh El Nino terlihat pada bulan kering tahun 2015 dimana anomali negatif terjadi lebih dominan, sedangkan pada tahun 2016 pada saat kondisi La Nina, cenderung terjadi anomali positif sehingga lebih banyak mendukung terjadinya pertumbuhan awan yang berpotensi hujan. Dari parameter angin, terlihat jelas faktor El Nino Kuat dan La Nina Lemah mempengaruhi angin zonal dan meridional di Indonesia. Angin zonal saat EI Nino lebih dominan angin timuran, dan angin meridional lebih dominan angin dari selatan yang menyebabkan terjadinya pengurangan suplai uap air di Indonesia. Sebaliknya saat kondisi La Nina angin zonal lebih dominan baratan dan angin meridional lebih dominan dari utara. Sedangkan dari parameter curah hujan terlihat jelas pada periode EI Nino Kuat cenderung terjadi anomali negatif dan pada periode La Nina terjadi anomali yang positif.

Pada kejadian El Nino kuat dan La Nina lemah pada tahun 2015 dan 2016 dapat dilihat pengaruhnya di wilayah Indonesia terutama 
terlihat di wilayah Indonesia Bagian Selatan, seperti Jawa, Bali, Nusa Tenggara dan Sulawesi Selatan. Hal ini dapat dijadikan sebagai bahan antisipasi dan pertimbangan untuk menghadapi fenomena El Nino atau La Nina pada tahuntahun berikutnya sehingga efek bencana hidrometeorologi seperti kekeringan atau banjir dan tanah longsor dapat diminimalisir.

\section{DAFTAR PUSTAKA}

Aldrian, E. (2000). Pola Hujan Rata-Rata Bulanan Wilayah Indonesia; Tinjauan Hasil Kontur Data Penakar dengan Resolusi ECHAM T-42. Jurnal Sains \& Teknologi Modifikasi Cuaca, 1(2), 113-123.

Aldrian, E. (2002). Spatial Patterns of ENSO Impact on Indonesian Rainfall. Jurnal Sains \& Teknologi Modifikasi Cuaca, 3(1), 5-15.

Aldrian, E., Susanto R.D. (2003). Identification of Three Dominant Rainfall Regions within Indonesia and Their Relationship to Sea Surface Temperature. International Journal of Climatology, 23(12), 1435-1452. doi: 10.1002/joc.950

Aldrian, E., Gates, L.D., Widodo, F.H. (2003). Variability of Indonesian Rainfall and the Influence of ENSO and Resolution in ECHAM4 Simulations and in the Reanalyses. MPI Report 346, 30pp. Max Planck-Institut für Meteorologie, Hamburg, Germany.

As-Syakur, A.R., Tanaka, T., Prasetia, R., Swardika, I.K., Kasa, I.W. (2011). Comparison of TRMM Multisatellite Precipitation Analysis (TMPA) Products and Daily-Monthly Gauge Data over Bali. International Journal of Remote Sensing, 32(24), 8969-8982. doi: $10.1080 / 01431161.2010 .531784$

Boer, R. (2003). Penyimpangan Iklim di Indonesia. Makalah Seminar Nasional IImu Tanah. KMIT Jurusan Tanah Fakultas Pertanian UGM. Yogyakarta.
Boer, R., Faqih, A., Ariani, R. (2014). Relationship Between Pacific and Indian Ocean Sea Surface Temperature Variability and Rice Production, Harvesting Area and Yield in Indonesia. Paper presented in EEPSA conference on The Economics of Climate Change, 27-28 February. Siem Reap, Cambodia.

Hendon, H.H. (2003). Indonesian Rainfall Variability: Impacts of Enso and Local Air Sea Interaction. Journal of Climate, 16(11), 1775-1790. doi: 10.1175/15200442(2003)016<1775:Irvioe>2.0.Co;2

Ihara, C., Kushnir,Y., Cane, M.A. (2008). Warming Trend of the Indian Ocean SST and Indian Ocean Dipole from 1880 to 2004. Journal of Climate, 21(10), 20352046. doi: $10.1175 / 2007$ JCLI1945.1

Irawan, B. (2006). Fenomena Anomali Iklim EI Nino dan La Nina - Kecenderungan Jangka Panjang dan Pengaruhnya terhadap Produksi Pangan. Jurnal Forum Penelitian Agro Ekonomi, 24(1), 28-45.

Meyers, G., Mcintosh, P., Pigot, L., Pook, M. (2007). The Years of El Nino, La Nina, and Interactions with the Tropical Indian Ocean. Journal of Climate, 20(13), 28722880. doi: $10.1175 / \mathrm{JCL} 14152.1$

Mulyana, E. (2002). Analisis Angin Zonal di Indonesia Selama Periode ENSO. Jurnal Sains \& Teknologi Modifikasi Cuaca, 3(2), 115-120.

Prawirowardoyo, S. (1996). Meteorologi. Bandung: Penerbit ITB.

Visa, J., Marpaung, S., Adikusumah, N. (2012). Karakteristik Angin Zonal dan Meridional pada Saat Musim Basah dan Kering di Wilayah Indonesia. Penelitian Masalah Lingkungan di Indonesia 2012, 27-35.

Xie, P., Chen, M., Yang, S., Yatagai, A., Hayasaka, T., Fukushima, Y., Liu, C. (2007). A Gauge Based Analysis of Daily Precipitation over East Asia. Journal of Hydrometeorology, 8(3), 607-626. doi: 10.1175/JHM583.1 